\title{
EFEKTIFITAS PENDIDIKAN KESEHATAN TERHADAP SIKAP HIDUP BERSIH DAN SEHAT DALAM PENCEGAHAN SKABIES DI PONDOK PESANTREN MUKHTARIYAH SYAFI'IYAH 1 BEJI TUBAN (The Effectiveness of Health Education on Attitude about Clean and Healthy in the Prevention of Scabies)
}

\author{
Titik Sumiatin, Binti Yunariyah, Wahyu Tri Ningsih \\ Poltekkes Kemenkes Surabaya Prodi Keperawatan Tuban \\ email: bojoneahsan@yahoo.com
}

\begin{abstract}
Scabies is known in Indonesia as skin diseases commonly known as a skin disease caused by infestation and sensitization to saccoptes scabiei. Scabies is also known as infectious disease worldwide with an estimated 300 million cases annually. This prevalence varies and fluctuates every time. The prevalence of scabies in Indonesia is around 6-27\% of the general population. The purpose of this study was to determine changes in attitude about clean and health life of students after being given health education.The research design was Pre Experimental design. The population was all students in boarding school of Mukhtariyah Shafi'ites 1 in Beji village, district. Jenu Kab. Tuban. The sample was 80 people determined by random sampling. The Data was collected using a questionnaire which was then analyzed by Spearman and Wilcoxon tests. The results showed attitudeof boarding schoolstudents about clean and healthy life in preventing the scabies disease before being given health education and after being given health education has increased. The test results analysis using the Wilcoxon Sign Rank Test showed pretest and post-test yield value of $p=0.000(<0.05)$, which means it was very significant. Health education was very effective in changing attitude of students, so it was advisable to further improve the implementation of health education at the boarding school in the district of Tuban.
\end{abstract}

Keywords: Attitude, Clean and Health, Scabies

\begin{abstract}
Abstrak: Scabies dikenal di Indonesia sebagai penyakit kulit. Lebih sering dikenal dengan penyakit gudik yaitu penyakit kulit yang disebabkan oleh infestasi dan sensitisasi terhadap saccoptes scabiei. Skabies juga dikenal sebagai penyakit menular yang mendunia dengan estimasi 300 juta kasus setiap tahunnya. Prevalensi ini bervariasi dan fluktuatif setiap waktunya. Prevalensi penyakit skabies di Indonesia adalah sekitar 6-27\% dari populasi umum. Tujuan dari penelitian ini adalah mengetahui perubahan Sikap tentang hidup bersih dan sehat santri setelah diberikan pendidikan kesehatan. Desain penelitian menggunakan Pre Experimental design. Populasinya adalah seluruh santri yang di pondok pesantren Mukhtariyah Syafi'iyah 1 di Desa Beji, Kec. Jenu Kab. Tuban. Sampel ditentukan secara random sampling yaitu 80 orang. Data dikumpulkan menggunakan kuesioner yang selanjutnya dianalisis dengan uji statistik Spearman dan uji Wilcoxon.Hasil penelitian menunjukkan Sikap Santri pondok pesantren tentang hidup bersih dan sehat dalam mencegah penyakit skabies sebelum diberikan pendidikan kesehatan dan setelah diberikan pendidikan kesehatan mengalami peningkatan. Sesuai hasil uji Analisis menggunakan uji Wilcoxon Sign Rank Test pada data pretest dan post-test menghasilkan nilai $\mathrm{p}=0,000(<0,05)$, yang berarti sangat signifikan.Pendidikan kesehatan sangat efektif dalam merubah sikap santri, sehingga sangat disarankan untuk lebih meningkatkan pelaksanaan pendidikan kesehatan di pondok-pondok yang ada di wilayah Kabupaten Tuban.
\end{abstract}

Kata Kunci: Sikap, hidup bersih dan sehat, Skabies 
Scabies dikenal di Indonesia sebagai penyakit kulit. Lebih sering dikenal dengan penyakit gudik yaitu penyakit kulit yang disebabkan oleh infestasi dan sensitisasi terhadap saccoptes scabiei. (Daili, Emmy S.S, dkk, 2005).

Skabies juga dikenal sebagai penyakit menular yang mendunia dengan estimasi 300 juta kasus setiap tahunnya. Prevalensi ini bervariasi dan fluktuatif setiap waktunya (Farrar et al., 2014). Prevalensi penyakit skabies di Indonesia adalah sekitar 6-27\% dari populasi umum. Skabies menduduki peringkat ke-3 dari penyakit kulit tersering di Indonesia. Di suatu pesantren yang padat penghuninya, prevalensi skabies mencapai 78,7\% dan lebih tinggi pada kelompok dengan higiene kurang baik (Sungkar, 1995). Insidensi dapat bersifat endemik yang meningkat pada anak-anak, remaja, lansia, pasien tirah baring, dan tingkat pendidikan yang rendah (Kowalak, 2003; Zayyid et al., 2010; Nazari \& Azizi, 2014). Namun hal ini tidak signifikan karena skabies menginfestasi semua individu tanpa memandang jenis kelamin, usia, maupun ras (Turkington \& Ashby, 2007). Penyakit ini terjadi 2-6 minggu pada seseorang yang belum pernah terinfeksi sebelumnya dan 1-4 hari pada seseorang dengan riwayat penyakit skabies sebelumnya (Cameron et al., 2012). Menurut Kong (2009), cara pengobatan yang tepat sangat penting untuk mencegah kegagalan terapi. Kegagalan terapi ini juga dapat disebabkan kurangnya pengetahuan dan pendidikan yang rendah (Schaider et al., 2012)

Berdasarkan hasil penelitian yang dilakukan di Pondok Pesantren di Kabupaten Lamongan (Jawa Timur) diperoleh hasil 64,2\% yang menderita scabies (Marufiisa, 2005).

Kondisi lingkungan pesantren dan kepadatan hunian dapat mempengaruhi kesehatan santri, terutama diantaranya dalam penularan skabies. Salah satu faktor penularan skabies ini terjadi apabila santri tidak paham tentang pentingnya menjaga kebersihan lingkungan maupun kebersihan pribadi. Para santri perlu mengetahui bagaimana cara penularan skabies sehingga dapat melakukan upaya preventif yang tepat. Sesuai dengan teori Lawrence Green yang menyatakan bahwa perilaku seseorang akan dipengaruhi oleh pengetahuan, sikap, kepercayaan dan didukung oleh lingkungan fisik, tersedia atau tidaknya fasilitas dan sarana kesehatan. Oleh karena itu petugas kesehatan perlu melakukan intervensi dalam pencegahan skabies dengan memberikan pemahaman yang komprehensif tentang skabies terhadap santri di lingkungan pesantren. Bila masalah skabies dalam pondok pesantren tidak segera ditangani maka akan timbul dampak pada santri yaitu karena tingkat penularannya yang tinggi akan sangat mudah menularkannya pada santri lain, mengganggu konsentrasi pada saat santri sedang belajar dan mengganggu ketenangan pada waktu istirahat, terutama pada waktu tidur dimalam hari (Marufiisa dkk, 2005).

\section{BAHAN DAN METODE}

Desain penelitian yang digunakan dalam penelitian ini adalah Pre Experimental design. Populasi dalam penelitian ini adalah semua santri yang di pondok pesantren Mukhtariyah Syafi'iyah 1 di Desa Beji, Kec. Jenu Kab. Tuban. Besar populasi dalam penelitian ini yaitu 100 santri. Sampel dalam penelitian ini adalah sebagian santri pondok pesantren Mukhtariyah Syafi'iyah 1 Beji Tuban.

Teknik sampling yang digunakan adalah simple random sampling. Pengumpulan data dilakukan dengan menggunakan kuesioner. Uji statistik yang digunakan adalah Spearman untuk mengetahui pengaruh pengetahuan, sedangkan untuk membandingkan pre dan post digunakan uji Wilcoxon.

\section{HASIL PENELITIAN}

\section{Tabel 1 Distribusi Karakteristik Santri Berdasarkan Umur di Pondok Pesantren Mukhtariyah Syafi'iyah 1 Beji Tuban}

\begin{tabular}{ccc}
\hline Umur(Tahun) & Jumlah & Prosentase(\%) \\
\hline 14 & 10 & 12,5 \\
15 & 16 & 20 \\
16 & 21 & 26,25 \\
17 & 17 & 21,25 \\
18 & 8 & 10 \\
19 & 5 & 6,25 \\
20 & 2, & 2,50 \\
21 & 1 & 1,25 \\
\hline Total & $\mathbf{8 0}$ & $\mathbf{1 0 0}$ \\
\hline
\end{tabular}

Santri yang dijadikan responden adalah semua perempuan dan sebagian besar berumur 16 tahun $(26,25 \%)$.

Tabel 2 menunjukkan Sikap santri pondok pesantren Mukhtariyah Syafi'iyah 1 Beji Tuban tentang hidup bersih dan sehat dalam mencegah penyakit skabies sesudah diberikan pendidikan kesehatan lebih baik daripadasebelumdiberikan pendidikankesehatan. Analisis menggunakan uji Wilcoxon Sign Rank Test pada data pretest dan 
Tabel 2 Sikap santri pondok pesantren Mukhtariyah Syafi'iyah 1 Beji Tuban tentang hidup bersih dan sehat dalam mencegah penyakit skabies sebelum dan sesudah diberikan pendidikan kesehatan

\begin{tabular}{lcccc}
\hline \multirow{2}{*}{ SIKAP } & \multicolumn{2}{c}{ PRE TES } & \multicolumn{2}{c}{ POST TES } \\
\cline { 2 - 5 } & Jumlah & Prosentase (\%) & Jumlah & Prosentase (\%) \\
\hline Sangat Negatif & 0 & 0 & 0 & 0 \\
Negatif & 2 & 2.5 & 2 & 2.5 \\
Positif & 46 & 57.5 & 35 & 43.75 \\
Sangat Positif & 32 & 40 & 43 & 53.75 \\
\hline Total & $\mathbf{8 0}$ & $\mathbf{1 0 0}$ & $\mathbf{8 0}$ & $\mathbf{1 0 0}$ \\
\hline
\end{tabular}

Wilcoxon Sign Rank Test $r=0,003$

post-test menghasilkan nilai $\mathrm{p}=0,000(<0,05)$, menunjukkan sikap setelah diberikan pendidikan kesehatan secarasignifikan lebih baik dari pada sebelum diberikan pendidikan kesehatan.

\section{PEMBAHASAN}

\section{Sikap Santri sebelum diberikan Pendidikan Kesehatan}

Sikap Santri pondok pesantren Mukhtariyah Syafi'iyah 1 Beji Tuban tentang hidup bersih dan sehat dalam mencegah penyakit skabies sebelum diberikan pendidikan kesehatan sebagian besar adalahpositif $(57,5 \%)$.

Sikap adalah determinan perilaku, karena berkaitan dengan persepsi, kepribadian, dan motivasi. Sebuah sikap merupakan suatu keadaan sikap mental, yang dipelajari dan diorganisasi menurut pengalaman, dan yang menyebabkan timbulnya pengaruh khusus atas reaksi seseorang terhadap orang-orang, objek-objek, dan situasi-situasi dengan siapa ia berhubungan (Winardi, 2004).

Sebagian besar santri sudah memiliki sikap yang positif, meskipun belum mendapatkan pendidikan kesehatan karena dalam ajaran islam juga sudah diajarkan bahwa "Kebersihan adalah sebagian dari Iman". Sedikit atau banyak santri sudah berusaha menerapkan hidup bersih dan sehat, meskipun masih jauh dari standar yang seharusnya.

\section{Sikap Santri setelah diberikan Pendidikan Kesehatan}

Sikap santri pondok pesantren Mukhtariyah Syafi'iyah 1 Beji Tuban tentang hidup bersih dan sehat dalam mencegah penyakit skabies setelah diberikan pendidikan kesehatan lebih dari separuhnyasangatpositif $(53,75 \%)$.
Menurut Zimbardo dan Ebbesen, sikap adalah suatu predisposisi (keadaan mudah terpengaruh) terhadap seseorang, ide atau obyek yang berisi komponen-komponen cognitive, affective dan behavior (Ahmadi, 1999).

Perubahan yang signifikan juga terjadi terhadap sikap antara sebelum dan sesudah pendidikan kesehatan, dari semula bersikap positif meningkat menjadi sangat positif. Sebagai akibat perubahan pengetahuan diharapkan akan membawa dampak terhadap perubahan sikap dalam mencegah skabies.

Sikap santri tentang hidup bersih dan sehat dalam pencegahan penyakit skabies sebelum dan sesudah diberikan pendidikan kesehatan

Sikap santri pondok pesantren Mukhtariyah Syafi'iyah 1 Beji Tuban tentang hidup bersih dan sehat dalam mencegah penyakit skabies sesudah diberikan pendidikan kesehatan mengalami peningkatan. Dari sebagian besar mempunyai sikappositif menjadi sebagian besar mempunyai sikap sangat positif. Melalui Analisis dengan menggunakan uji Wilcoxon Sign Rank Test pada data pretest dan post-test menghasilkan nilai $\mathrm{p}=0,000(<0,05)$, menunjukkan sikap setelah diberikan pendidikan kesehatan secarasignifikan lebih baik daripada sebelum diberikan pendidikan kesehatan.

Sikap santri pondok pesantren Mukhtariyah Syafi'iyah 1 Beji Tuban tentang hidup bersih dan sehat dalam mencegah penyakit skabies sesudah diberikan pendidikan kesehatan lebih baik dari pada sebelum diberikan pendidikan kesehatan. Analisis menggunakan uji Wilcoxon Sign Rank Test pada data pretest dan post-test menghasilkan nilai $\mathrm{p}=0,000(<0,05)$, menunjukkan sikap setelah diberikan pendidikan kesehatan secarasignifikan lebih baik dari pada sebelum diberikan pendidikan kesehatan. 
Sikap adalah determinan perilaku, karena mereka berkaitan dengan persepsi, kepribadian, dan motivasi. Sebuah sikap merupakan suatu keadaan sikap mental, yang dipelajari dan diorganisasi menurut pengalaman, dan yang menyebabkan timbulnya pengaruh khusus atas reaksi seseorang terhadap orang-orang, objek-objek, dan situasi-situasi dengan siapa ia berhubungan (Winardi, 2004). Menurut Zimbardo dan Ebbesen, sikap adalah suatu predisposisi (keadaan mudah terpengaruh) terhadap seseorang, ide atau obyek yang berisi komponenkomponen cognitive, affective dan behavior (Ahmadi, 1999).

Sikap santri sebelum dan sesudah mendapatkan pendidikan kesehatan mengalami peningkatan atau menjadi lebih baik, karena pengetahuan mereka juga mengalami perubahan. Dari informasi yang diberikan melalui pendidikan kesehatan yang spesifik tentang skabies, secara langsung membawa perubahan sikap pada santri yang memungkinkan untuk mereka lakukan di pondok, dengan menggunakan fasilitas dan sarana yang ada

\section{SIMPULAN DAN SARAN}

\section{Simpulan}

Pendidikan kesehatan efektif merubah sikap santri tentang hidup bersih dan sehat dalam pencegahan skabies

\section{Saran}

Sebaiknya pihak pondok pesantren menjalin kerjasama dengan dinas kesehatan atau pelayanan kesehatan terdekat, untuk memfasilitasi berbagai masalah yang berhubungan dengan kesehatan yang dialami oleh Pondok pesantren, dan Institusi kesehatan dapat memperluas kegiatan penyuluhan di seluruh Pondok Pesantren di Wilayah Kabupaten Tuban, Santri lebih meningkatkan kebersihan diri setelah mendapat pengetahuan, agar bebas dari penyakit skabies

\section{DAFTAR PUSTAKA}

Andayani L. 2007. Perilaku Santri dalam Upaya Pencegahan Penyakit Skabies di Pondok Pesantren Ulumu Qur'an Stabat. Medan

Aryani R. 2010.Kesehatan Remaja Problem dan Solusinya. Jakarta: Salemba Medika.
Bukhart C. 1997.Scabies: An Epidemiologic Reassessment. Majalah Kedokteran Indonesia 47 (1).. hal: $117-123$.

Catmoki. 2007. Scabies. (Online), (http:/www. catmoki. id/ Scabies, diakses 1 oktober 2017)

Daili, Emmy S.S, dkk. 2005. Penyakit Kulit Yang Umum Di Indonesia. Jakarta Pusat : PT Medikal Multimedia Indonesia

Djuanda, Adhi. 2005. Ilmu Penyakit Kulit dan Kelamin. Jakarta : Balai Penerbit FKUI

Fernawan N. 2008. 'Perbedaan Angka Kejadian Skabies Di Kamar Padat Dan Kamar Tidak Padat Di Pondok Pesantren Modern Islam PPMI Assalaam Surakarta'. Fakultas Kedokteran Universitas Muhammadiyah Surakarta.

Handajani S. 2007.'Hubungan Antara Kebersihan Diri Dengan Kejadian Skabies Di Pondok Pesantren Nihayatul Amal Waled Kabupaten Cirebon'. Fakultas Kedokteran Universitas Diponegoro.

Harahap, Marwali. 2008. Ilmu Penyakit Kulit. Jakarta: PT Gramedia.

Mansjoer, Arif. 2000. Kapita Selekta Kedokteran. Jakarta: FKUI.

McCarthy JS, Kemp DJ, Walton SF, Currie BJ. 2004. Scabies: More Than Just An Irritation. Postgrad Med J. Jul 2004;80(945):382-7.

Makigami K, Ohtaki N, Ishii N, Yasumura S. 2009. Risk Factors Of Scabies In Psychiatric And Long-Term Care Hospitals: A Nationwide Mail-In Survey In Japan. J Dermatol. Sep 2009;36(9):491-8.

Muzakir. 2008. Faktor yang Berhubungan dengan Kejadian Penyakit Skabies pada Pesantren di Kabupaten Aceh Besar Tahun 2007. Medan.

Ma'rifu. 2005.Faktor Sanitasi Lingkungan yang berperan terhadap Prevalensi penyakit Scabies. Jurnal Kesehatan Lingkungan Vol 2. No 1 (11-18)

Notoadmodjo S. 2011. Kesehatan Masyarakat. Jakarta: Rineka Cipta.

Paramita N. 2010. Tingkat Pengetahuan Santri terhadap Penyakit Skabies di Pondok Pesantren Darularafah Raya. Medan.

Perry dan Potter. 2002. Fundamental Keperawatan. Jakarta: EGC

Rohmawati R. 2010. Hubungan antara faktor pengetahuan dan perilaku dengan kejadian skabies di Pondok Pesantren Al-Muayyad Surakarta. Surakarta. Diunduh: URL: http://id.scribd.com/ doc/130310770/Skripsi-Skabies.

Slamet, Juli Soemirat. 1996. Kesehatan Lingkungan. Bandung: Gajah Mada University Press

Sungkar, S. 2000. Skabies. Jakarta: Yayasan Penerbit Ikatan Dokter Indonesia. 